Friends of God 


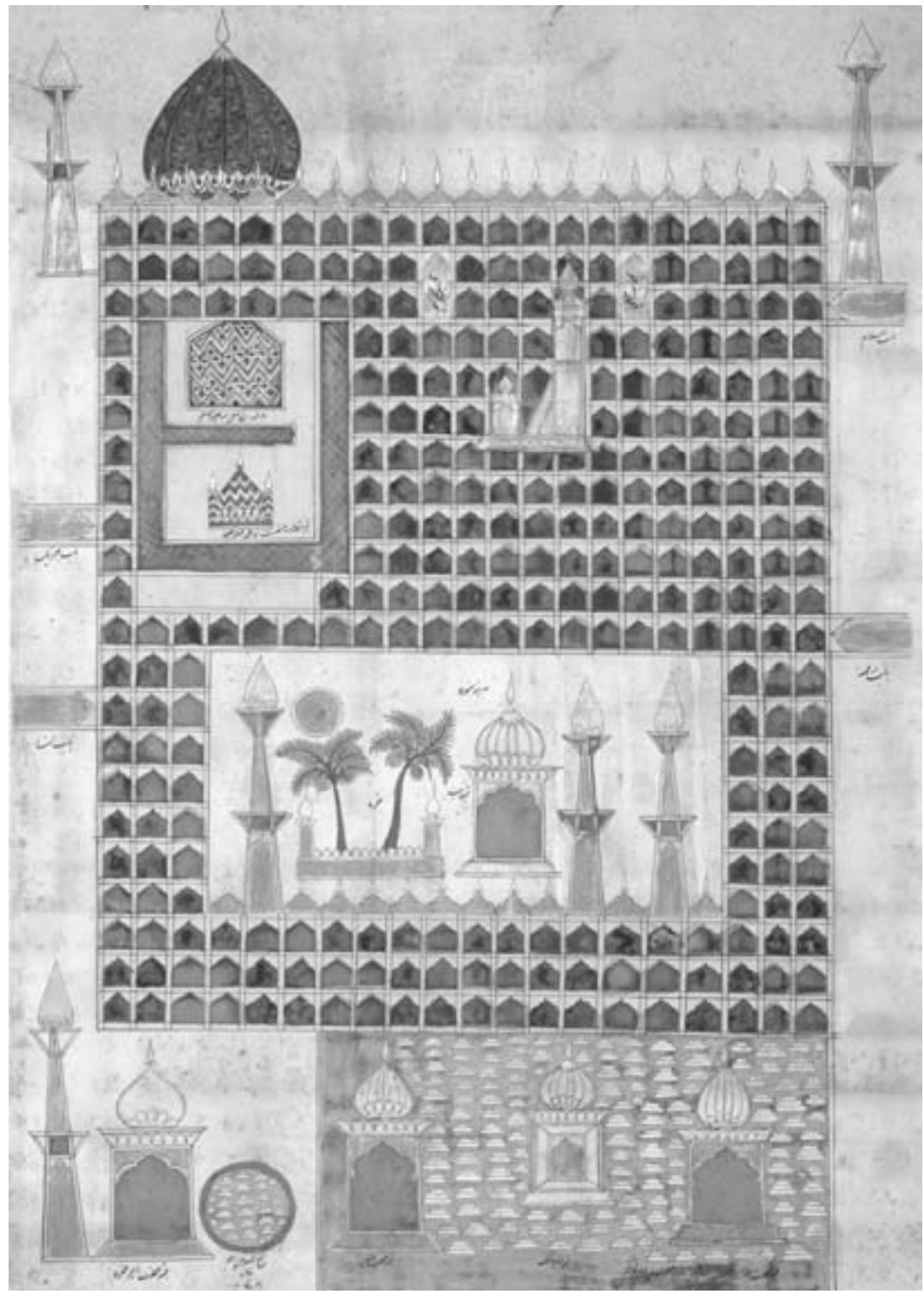

FrontisPiece. This plan of the Prophet's mosque in Medina, al-Haram an-Nabawī, shows (with green domes) the burial places of Muhammad and Fātima (top left); Muhammad's wife Zaynab (in courtyard); in the cemetery at bottom: Muhammad's uncle 'Abbās, grandson Hasan, Muhammad Bāqir, and Ja'far as-Sādiq (second, fifth, and sixth Shī'ī imams, all on the right); legal scholar Mālik ibn Anas and third caliph 'Uthmān (to the left); further left outside the cemetery, Muhammad's legendary uncle Hamza. Arabia or India, eighteenth-early nineteenth century; The Nasser D. Khalili Collection of Islamic Art, MSS 745.2. 


\title{
Friends of God
}

Islamic Images of Piety, Commitment, and Servanthood

\author{
JOHN RENARD
}

只

University of California Press

BERKELEY LOS ANGELES LONDON 
University of California Press, one of the most distinguished university presses in the United States, enriches lives around the world by advancing scholarship in the humanities, social sciences, and natural sciences. Its activities are supported by the UC Press Foundation and by philanthropic contributions from individuals and institutions. For more information, visit www.ucpress.edu.

University of California Press

Berkeley and Los Angeles, California

University of California Press, Ltd.

London, England

(C) 2008 by The Regents of the University of California

Library of Congress Cataloging-in-Publication Data

Renard, John, 1944-

Friends of God : Islamic images of piety, commitment, and servanthood / John Renard.

p. $\quad \mathrm{cm}$.

Includes bibliographical references and index.

ISBN: 978-0-520-24291-3 (cloth : alk. paper)

ISBN: 978-o-520-25198-4 (pbk. : alk. paper)

1. Islamic hagiography—History and criticism. 2. Legends, Islamic-History and criticism. I. Title.

BP189.43.R46 2008

$297.6^{\prime} 1-\mathrm{dc} 22$

2007028542

Manufactured in the United States of America

$\begin{array}{llllllllll}17 & 16 & 15 & 14 & 13 & 12 & 11 & 10 & 09 & 08 \\ 10 & 9 & 8 & 7 & 6 & 5 & 4 & 3 & 2 & 1\end{array}$

This book is printed on New Leaf EcoBook 50, a 100\% recycled fiber of which $50 \%$ is de-inked post-consumer waste, processed chlorine-free. EcoBook 50 is acid-free and meets the minimum requirements of ANSI/ASTM D5634-O1 (Permanence of Paper). 
With gratitude to my parents, Virginia M. Renard (1915-2006) and George J. Renard (1911-), for sharing their desire for God's Friendship 
